\title{
A CHURCH ROMANCE
}

\section{Mellstock : circa 1835}

SHE turned in the high pew, until her sight Swept the west gallery, and caught its row Of music-men with viol, book, and bow Against the sinking sad tower-window light.

She turned again; and in her pride's despite One strenuous viol's inspirer seemed to throw A message from his string to her below, Which said: 'I claim thee as my own forthright!'

Thus their hearts' bond began, in due time signed. And long years thence, when Age had scared Romance, At some old attitude of his or glance That gallery-scene would break upon her mind, With him as minstrel, ardent, young, and trim, Bowing 'New Sabbath' or 'Mount Ephraim.' 